Bayero Journal of Pure and Applied Sciences: 10(1): 173 - 179

ISSN 2006 - 6996

\title{
CHALLENGES OF SUSTAINABLE LIVING ENVIRONMENT IN DAMATURU TOWN, YOBE STATE, NIGERIA
}

\author{
Akhilendra Nath Tiwary \\ Faculty of Social and Management Sciences \\ Yobe State University, KM 7 Gujba Road, PMB 1144, Damaturu, Yobe State, Nigeria \\ Email: antiwary2000@gmail.com; +2348185318874 and +2347083998024
}

\begin{abstract}
Urban development of the world in last three decades is phenomenal. It has risen from less than $20 \%$ to more than $54 \%$ and likely to cross $75 \%$ by 2030 . Today, majority of urban research are focused on big metros of developed countries, ignoring the fact that vast urban population live in small and medium cities of developing countries. Globalization has accelerated urbanization in the developing world, but at the cost of their living environment facing numerous challenges of sustainability viz; lack of basic amenities and facilities, health, education, poverty, environmental degradation, etc. The present study attempts to find out major challenges towards sustainable living environment of Damaturu town in Yobe State, Nigeria. Total number of 122 respondents were selected by systematic random sampling for questionnaire based survey in three sample wards of the town representing $10 \%$ of the total 1200 housing units. Personal interviews with the civil servants, lawyers, academicians, politicians and NGOs were also conducted for identification of major problems and challenges. The research finding recommends shifting the policy approach from centralized to bottom up with common people's participation based on their needs and demands. Community based development projects should focus on major areas of water, electricity, housing, drainage \& sewerage and waste management for ensuring a sustainable living environment.
\end{abstract} Keywords: Urbanization, people's participation, sustainable development goals

\section{INTRODUCTION}

Rapid urbanization of the world will cross urban population as more than $50 \%$ of the world population by next decade. In Africa, transformation of rural population in urbanising society with limited infrastructure amenities and facilities are posing considerable stress on living environment. The problems are aggravated with inadequate urban development plan. Africa's urban transition is partially accompanied by economic growth derived mainly from non-agricultural valueadded, the growth is largely un-sustained, and far below the level required to significantly reduce poverty levels, as urban areas sprawl at the cities' peripheries, the core areas

break down with the burden from increasing demand for social services, which consequently become homes of the poor, and the sites and sources of environmental pollution (Kessides, 2005). As the world's cities absorb tremendous growth in human population, housing and public services in these areas have not kept pace, particularly in less developed countries where overall population growth is more pronounced and urban crowding is most severe (Olalekan, 2014). Over $40 \%$ Nigerians now live in urban centres of varying sizes (Olotua and Bobadoye, 2009). The explosive rates of growth have complicated and exacerbated inter-related problems of human settlements and environment, but have also greatly accelerated poverty (Oladunjoye, 2005). In 1931, 6.7 per cent of Nigerians lived in urban centres, that is settlements with populations of 20,000 and above. The proportion rose to 10.2 per cent in 1952. 19.2 per cent in $1963,25.1 \%$ in $1972,33 \%$ in 1984 and $42 \%$ in 1991 which was to reach $68 \%$ by 2020 (Onibokun, 1987a; 1989; 1990a). According to World Data Atlas (2017), the urban population has reached $48.16 \%$ of the total population in Nigeria. Nigeria as a developing country appear to be facing a more rapid rate of urbanization, mainly as a result of ruralurban migration. Mabogunje (2002) has written about today's Nigerian cities characterized by substandard and inadequate housing, slums, and lack of infrastructure, transportation problems, low productivity, poverty, crime and juvenile delinquency. Damaturu is a relatively new town serving as the capital of Yobe state which was carved out for Borno State in 1991. The rapid growth of Damaturu accompanied by desire for building spaces to meet the urgent need for residential, commercial and public buildings have undoubtedly led to unhealthy urban growth (Daura et al, 2010). 
Sudden mass movement into Damaturu brought about significant changes in development pattern, engulfment of nearby settlements and buildings without resort to land use planning norms, values and conversion of existing forest reserves to residential use. In Damaturu except Damakasu, Damaturu central and Sasawa/ Kabaru wards the disposal of sachet waste is not organised. $66 \%$ of the total waste generated is littered on streets, grounds or backyards of residences and drains. $11 \%$ is burnt, $3 \%$ is buried, $14 \%$ is put into public bins and remaining only $6 \%$ is reused (Tiwary, M.R. 2015).

Statement of the Problems

Drinking water, electricity, drainage, sewerage, sa Ulcer, Malaria and Typhoid are directly linked with the poor living environment of the town.

Aim and Objectives

The main aim of the paper is to find out solutions of the existing challenges and problems towards sustainable living environment of Damaturu with following objectives:

1. To assess the possibilities of improvement in the civic amenities and facilities leading to sustainable living environment of Damaturu.

2. To find out the interrelationship between urban amenities and facilities with prevailing infrastructure.

3. To study the rural-urban continuum of Damaturu and its environ

4. To find out the solution to ensure sustainable living environment in Damaturu

\section{Scope and Limitation}

At the Sustainable Development Summit on 25th September 2015, UN Member States adopted 2030 Agenda for Sustainable Development, which included a set of 17 Sustainable Development Goals (SDGs) to end poverty, fight inequality and injustice, and tackle climate change by 2030 . The present study is limited to 11 th Sustainable Development Goal " Make cities and human settlements inclusive, safe, resilient and sustainable" (Sustainable Development Goals, 2015

http: / /www.un.org/sustainabledevelopment/ )

MATERIALS AND METHODS

Both primary and secondary data sources and

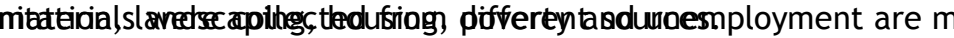

All the population data were collected from the latest Census published by National Population commission. The maps were collected from Ministry of Lands and Housing. For ethnographic research, four neighbouring villages were chosen namely; Khalalawa in north, Kasesa in south, Warsala in east and Bukar Kalam in west. These villages fall in periphery and Damaturu forms the core city. The people and their custom was closely observed and their socio economic condition in relation to the core was studied to find out root cause of underdevelopment in the peripheral area. In the core city, three wards were selected by systematic random sampling including half of female population. The sampled population was administered through questionnaire and their data was analysed to find out the issues, problems and challenges of the study area. The details of the sampling wards and size is follows (Table1):

Table 1: Sampling and Sample Size

\begin{tabular}{llcccc}
\hline S/N & Sample cluster & No of Houses & $\begin{array}{c}\text { Male } \\
\text { Respondents }\end{array}$ & $\begin{array}{c}\text { Female } \\
\text { Respondents }\end{array}$ & $\begin{array}{c}\text { Total Sample } \\
\text { Size (10\%) }\end{array}$ \\
\hline 1 & Abasha Ward & 319 & 16 & 16 & 32 \\
2 & Nayanya & 520 & 26 & 26 & 52 \\
3 & Sabon Pegi & 380 & 19 & 19 & 38 \\
Total & & 1219 & 61 & 61 & 122 \\
\hline
\end{tabular}

Source: Personal Field Survey, 2017

Study Area (Damaturu, capital of Yobe State) (Fig. 1)

Damaturu $\left(11^{\circ} 44^{\prime} 40^{\prime \prime}-11^{\circ} 45^{\prime} \mathrm{N}\right.$ and $11^{\circ}$ $\left.57^{\prime} 40^{\prime \prime} \mathrm{E}-11^{\circ} 58^{\prime} \mathrm{E}\right)$ is the capital of Yobe state in North Eastern Nigeria. Damaturu local government is bordered in the north by Tarmuwa local government, east by Kaga local government of Borno state, south by Gujba local government and west by Fune local government area respectively. Damaturu is pluralistic in ethnic composition with the tribes of Kanuri, Fulani, Hausa, Bolewa, Badawa, Bade, Gizim, Babur, Karekare etc. After Yobe state creation in 1991, some southern tribes (Igbo, Yorubas and Tivs) also migrated and got settled in the town as traders and civil servants. The Population of Damaturu was 30,970 persons in 1991 Census published by National Population Commission. It grew to 44,268 persons in 2006 (Census 2006). Damaturu being a capital town of Yobe state is predominantly inhabited by civil servant and traders. Education sector is predominantly under government sector with few private schools. Industrialisation is very poor with only brick and pure water processing plants in town. 
Two layouts named Damaturu Industrial layout I and II were designed and surveyed but no substantive development was observed in last two decade. Majority of population is involved in setting agricultural products and run small shops. They are completely dependent on two government hospitals for health services which are largely inadequate as the number of citizens is going to cross over hundred thousand very soon.

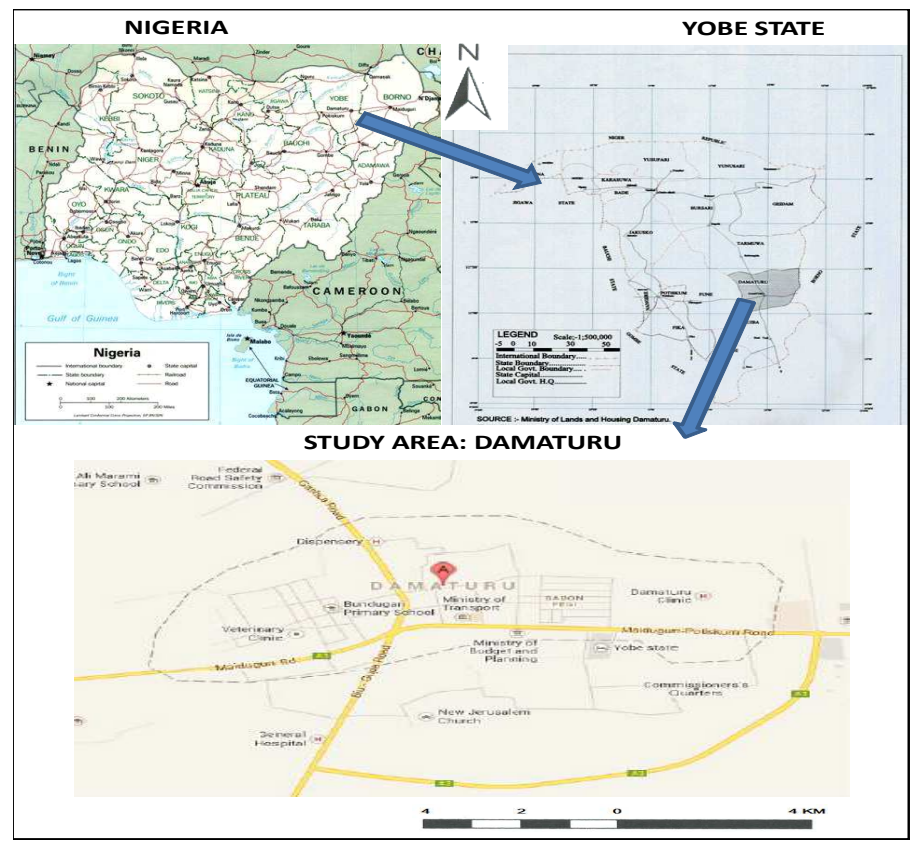

Figure 1: Location of the Study Area (Damaturu)

\section{RESULTS AND DISCUSSION}

The results show that the city has grown in size and population in last decade but at the cost of its living environment which has very high pressure and the civic authorities have failed to provide basic amenities and facilities of the citizens at the pace of fast urbanization. The results may be discussed as following:

1. Domestic Water supply: In the survey for existence of personal bohole, it was found that only $09 \%$ of the respondents have such facility with only $5 \%$ in Abasha ward, $10 \%$ in Nayanya and $12 \%$ in Sabon Pegi. Remaining $91 \%$ of the total population is dependent on private or community Bohole but such water gets polluted from collection to transportation process as it gets exposed to typhoid and Diarrhoea in due course (Fig 2).

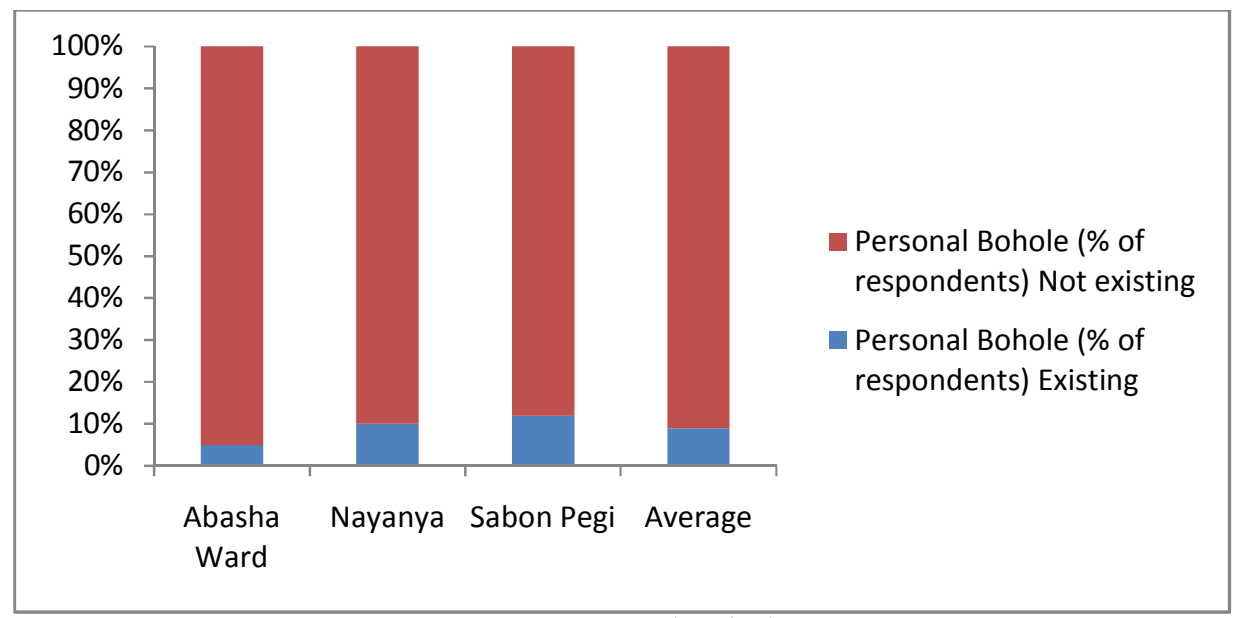

Fig 2: Existence of Personal Bohole in Damaturu Source: Personal Field Survey, 2017 
2. Electricity: In the question of National Electric Power Authority (NEPA) electric supply, $82 \%$ respondents recorded that the supply is below 12 hours with 80\% in Abasha Ward, 79\% in Nayanya and $88 \%$ in Sabon Pegi (Fig 3). The citizens have to depend heavily on the 2.7 to 4 KVA Chinese or locally assembled power generators which causes both air and noise pollution besides putting financial pressure on the people. One can't expect large scale economic activities in shortage of electric power. The state government has installed solar panels as street lights and government offices, but they are not affordable by common people.

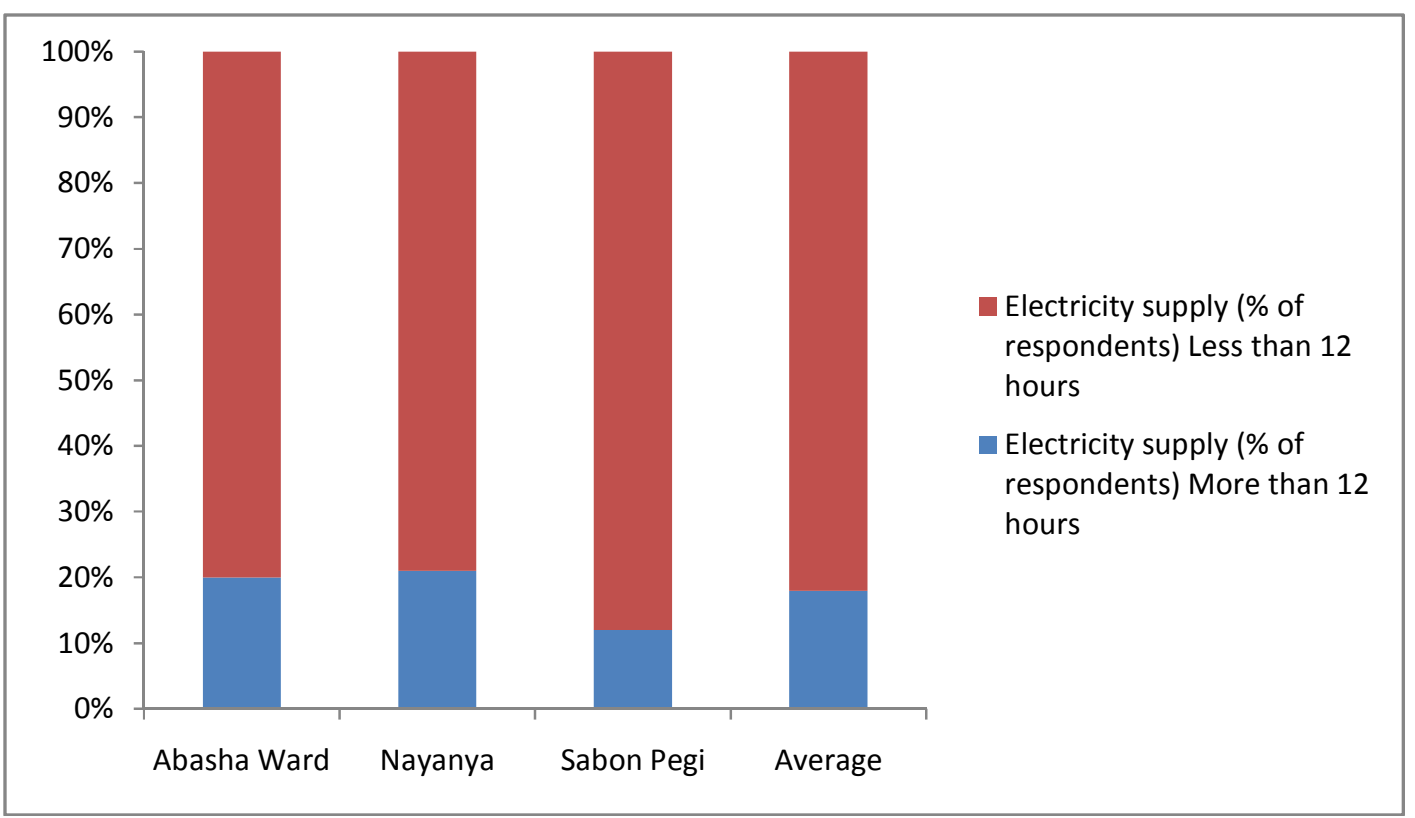

Fig. 3: Duration of electric Supply in Damaturu Source: Personal Field Survey, 2017

3. Drainage and Sewerage System: Total of $64 \%$ respondents reported absence of drainage and sewerage system with $70 \%$ in Abasha, $57 \%$ in Nayanya and $65 \%$ in Sabon Pegi (Fig. 4). Very limited network can be observed in few places.
These are poorly maintained. During rainy season, they become full of dirty water providing breeding ground for mosquitoes resulting in serious but common disease as typhoid and malaria.

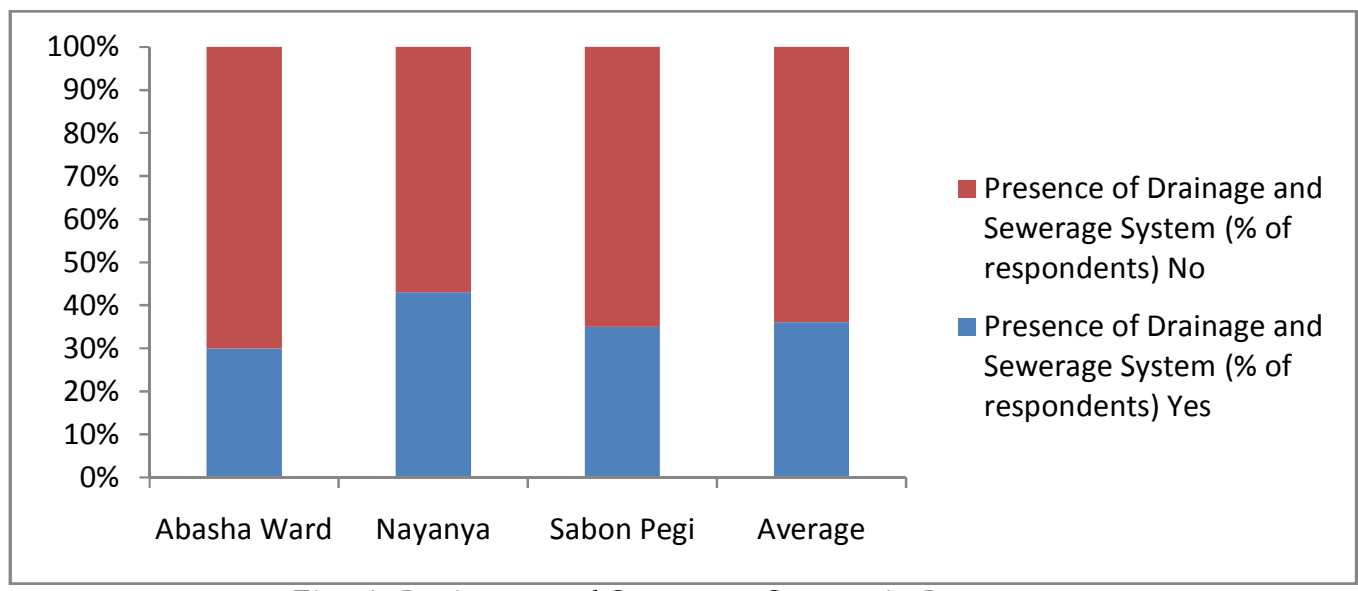

Fig. 4: Drainage and Sewerage System in Damaturu

Source: Personal Field Survey, 2017 
4. Provision of cleaning, fumigation and landscaping: The provision of cleaning, fumigation and landscaping by civic authorities is not satisfactory. None of the respondents gave excellent rating to the service. $40 \%$ of the respondents find it average while $50 \%$ rate it as poor (Table 2)

Table 2: Provision of cleaning, fumigation and landscaping in Damaturu

\begin{tabular}{|ccccc|}
\hline \begin{tabular}{|c} 
Provision of cleaning, fumigation and landscaping by civic authorities (\% of respondents) \\
Sample Wards
\end{tabular} & Excellent & Good & Average & Poor \\
\hline Abasha Ward & 00 & 05 & 50 & 45 \\
\hline Nayanya & 00 & 08 & 60 & 32 \\
\hline Sabon Pegi & 00 & 10 & 40 & 50 \\
\hline Average & 00 & 08 & 50 & 42 \\
\hline
\end{tabular}

Source: Personal Field Survey, 2017

5. Waste/Refuse management System: $90 \%$ of the respondents denied presence of any waste/refuse management in the city with $90 \%$ in Abasha, $86 \%$ in Nyanya and $94 \%$ in Sabon Pegi (Fig 5). However, they were happy that Yobe State Environmental Protection Agency (YOSEPA) has started keeping waste/refuse collection containers in city since last few months. The method adopted in collection, transportation and dumping is not scientific. The dumping site used by the civic authorities has been Babban Tsangaya in the city which has badly polluted the land and groundwater by seepage. On Complaints to civic authorities, new dumping ground has been selected opposite police headquarter. People litter their neighbourhood by dumping wastes or burn them polluting their immediate environment. Domestic wastes too chock the drainage and sewerage system which provides breeding ground for typhoid and malaria during rainy season. The incinerator in the hospital doesn't work which is another challenge for the living environment.

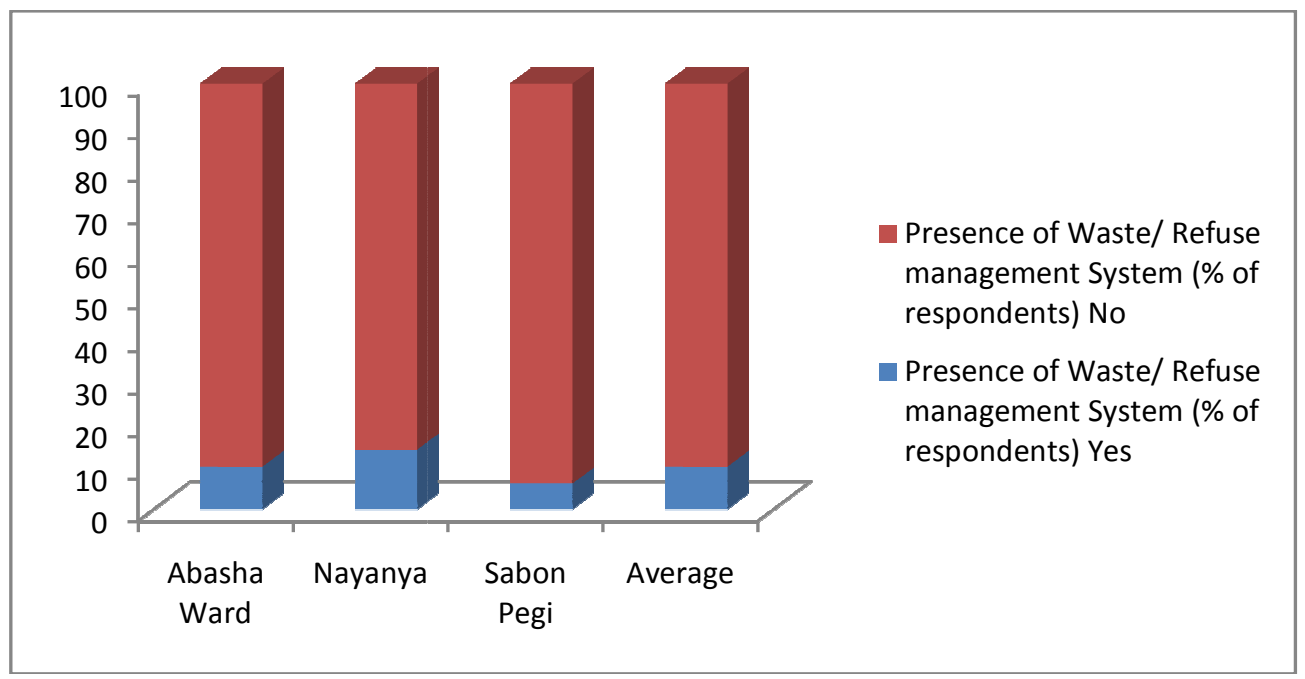

Fig 5: Waste/ Refuse management System in Damaturu Source: Personal Field Survey, 2017

6. Housing Types: Two prominent housing types were observed in field survey:

I. Permanent house types (DAKINKASA/FALLO): It is made up of brick, cement, concrete, wood and Zinc which is locally called as Dakinkasal Fallo. Many houses in Damaturu have zinc roofing now. In the sample wards, majority of the houses are permanent type.

II. Temporary house type (BUKA): It is made up of muds, clay, straw, light and weak materials locally called as Buka. They are used by agrarian and fulani cattle herders. Western side of the city towards Potiskum is a big village Bukar Kalam inhabited by Fulani tribe predominated with such house type. Inside town, one can't see such houses since last 2-3 years.

7. Economic Activities: The type of economic activities in the town can broadly be divided into following three types: 
I. Primary Economic Activities: Primary economic activities are related to agriculture farming, mining, fishing and animal husbandry. The farmers involved in selling agro products are excluded from this. $15 \%$ population is directly linked to such primary economic activities (Table 3).

II. Secondary Economic Activities: Among secondary economic activities, all industrial activities are included. Only brick making and pure water packaging industry is in existence in the town. There is no significant food processing or manufacturing industry in town which is one of the biggest drawback. 22\% of the sample population is involved in secondary activities which are not up to good standard (Table 3 ).

III. Tertiary Economic Activities: Such activities cover many business and services. There is a single warehouse in the city. Services in government sector are limited. In the private sector, some schools, clinics and small scale activities can be seen but they cannot be treated under organised sector. Majority of the people are involved in small commercial activities as selling food items, cloths, shoes, belts, bags, utensils, electronic and electric appliances, toys, mobiles, religious items, stationary items etc. In the service centre car washing, cycle repairs, hardware, barbing saloons, dry cleaning shops, etc., are common. These shops and service centres use Chinese or locally assembled gensets which are highly polluting to the environment. Out of 15 Petrol pumps in city, hardly 5-6 work throughout the year without any fixed fuel price. The transport depot is substandard and uncovered which is susceptible to Boko haram terrorist attacks every year. $63 \%$ of the total respondents are involved in such tertiary activities (Table 3 ).

Table 3: Type of Economic Activities in Damaturu

\begin{tabular}{|c|c|c|c|}
\hline \multirow{2}{*}{$\begin{array}{l}\text { Sample } \\
\text { Wards }\end{array}$} & \multicolumn{3}{|c|}{ Type of Economic Activities (\% of respondents) } \\
\hline & Primary & Secondary & Tertiary \\
\hline Abasha Ward & 28 & 30 & 42 \\
\hline Nayanya & 12 & 25 & 63 \\
\hline Sabon Pegi & 05 & 10 & 85 \\
\hline Average & 15 & 22 & 63 \\
\hline
\end{tabular}

Source: Personal Field Survey, 2017

\section{Conclusion}

Sustainable living environment can be ensured with fresh air, water and house to all the citizens. The citizens cannot get fresh air unless they get regular electric supply reducing dependence on polluting gensets. There is not a single park, recreational green open place or pond where people can breathe fresh air in morning and evening. The authorities should plan for establishing some agro based industries based on local products of grains and vegetables. Some of the agro industries that can be developed here may include cheese, butter, tomato ketchup, potato chips, yam frying sticks, corn flakes, various sausage, vegetable pickles, peanut and cashew nut processing and packaging, etc., It is not possible to establish basic industrial units as iron \&steel, cement and aluminium because of the lack of their required resources. Biochemical industry can be established as required resource is mineral oil which can be brought from Southern Nigeria. Establishment of bio chemical industry will boost production of medicines, polyesters for cloths, polyethylene for various packaging, storage, roofing, furniture, daily usage appliances etc. It will revolutionize leading to many sister units and change the under developed status of Yobe in general and Damaturu in particular. Proper Environmental Impact Assessment is required before establishing such industrial unit especially in relation to wind direction as powerful wind storm is common and it can be dangerous to citizens if not planned properly. The civic authorities have failed to provide drinking water supply to the citizens. They equally failed to control both surface and ground water pollution due to lack in any policy or planning. A proper perspective long term plan is required avoiding prioritized action of adopting ad hoc measures every year. The housing facilities of the city are Dakinkasa/Fallo with Zinc roofing. They continue to follow British model in which warm air is stuck under zinc roof. In severe storm, such house roofs get damaged. Ideally they should use indigene technique to make house or use concrete roofing to make them stable and comfortable. The land use of the town is confusing due to lack of any town (urban) and countryside (rural) planning. The civic authorities should demarcate land use zones and make a master plan based on people's participation. Present ad hoc plans are neither short term nor a perspective plan guided by the politicians with the help of some draftsmen without involving professional experts. 
It is important to look after the physical, socioeconomic, political and matters related to planning and administration which work together to achieve the Sustainable Development Goals for the development of the city (Tiwary, A.N, 2014). Isma'il et al. (2014) found extension of housing estates and other growth pulls along the high ways. It should be controlled to avoid linear bottleneck growth pattern . The use of modern tools and techniques of Remote Sensing (RS), Geographical Information System (GIS), Global Positioning System, etc. are required. The use of computer, survey analysis softwares (as;

\section{REFERENCES}

Census (2006) "National Population Commission of Nigeria", Provisional Figures for Census, Vol. 1, 2006, p. 22. Assessed on 5th July 2017 from http://www.population.gov.ng/index.ph p/publications/138-national-and-statepopulation-and-housing-tables-2006census-priority-tables-vol-1

Daura et al. (2010) "Problems of urbanization in Nigeria: A case study of Damaturu", International Journal of Environmental Issues, 6(1): 32-39.

Isma'il et al. (2014) "Analysis of Future Urban Growth Scenario of Damaturu Town in Yobe State, Nigeria", Global Journal of Research and Review (ISSN 2393-8854) p. 120

Kessides, C., (2005) The Urban Transition in SubSaharan Africa: Implications for Economic Growth and Poverty Reduction, Urban Development Unit, The World Bank

Mabogunje, A. (2002) Re-constructing the Nigerian City: The New Policy on Urban Development and Housing, Paper presented at a National Conference on the City in Nigeria, Ile Ife

Olalekan, B.G. (2014) "Urbanization, Urban Poverty, Slum and Sustainable Urban Development in Nigerian Cities: Challenges and Opportunities", Developing Country Studies, ISSN 2224$607 X$ (Paper) Vol.4, No.18, p. 15

Oladunjoye, A.O., (2005) Implementation of Sustainable City Programme in Nigeria, Havana 2005-Documentation of Experience SCP/LA21, Sustainable Cities Programme, Localizing Agenda 21 Programme, United Nations Environment Programme (UNEP), Nairobi, pg. 57,accessed on 10th March, 2017 from http: //www.unhabitat.org/la21

Olotua, A.O. and Bobadoye, S.A., (2009) Sustainable Housing Provision for the Urban Poor: A Review of Public Sector Intervention in Nigeria, The Built and Human Environment Review, (2), pp5163.
SPSS, NUD*ST) and Mapping Softwares (ARC GIS, Map Info, ERDAS, GEOMEDICA etc.) are the need of the hour (Tiwary, A.N., 2011). The government should look into the challenges as discussed above with help from experts professionals, academicians and local people. The approach should shift to decentralized with local people's participation based on their needs and demands focusing on basic amenities and facilities in terms of water, electricity, housing, drainage \& sewerage and waste management for ensuring a sustainable living environment.

Onibokun, A.G. (1987) The policy implications of emerging metropolises in Nigeria. In : Urban and Regional Planning Policy Formulation in Developing Countries. A. Faniran and A.G. Onibokun, eds. Ibadan University Press, Ibadan, Nigeria, pp. 91-104.

Onibokun, A.G. (1989) Urban growth and urban management in Nigeria. In : African Cities in Crisis. R.E. Stren and R.R. White, eds., West view Press, Boulder, Colorado, pp. 68-111.

Onibokun, A.G. (1990) Urban Housing in Nigeria. Nigerian Institute of Social and Economic Research, Ibadan

Onibokun, A.G. and Faniran, A. (1995) Urban Research in Nigeria. New edition [online]. Ibadan: Institut français de recherche en Afrique, 1995, assessed on 6th July 2017 from

http: / / books.openedition.org/ifra/534>.I SBN:9791092312188.DOI:10.4000/books. if ra. 53

Sustainable Development Goals (SDG) 2015. "17 Goals to Transform Our World" assessed on 15th July 2017 from http://www.un.org/sustainabledevelopm ent

Tiwary, A.N. (2011) An Appraisal of Urban Development and Planning of Mirzapur City (ISBN No. 978-3-639-35917-6), VDM Verlag Dr. Müller, Germany, p.128.

Tiwary, A.N. (2014) "Issues and Challenges in Sustainable Urban Development: A Case Study of Mirzapur City, U.P., India", International Journal of Management Research, Malaysia, (ISSN: 2321- 709), Vol.-2, Issue-6, June, 2014, p.107

Tiwary, M.R. (2015) "Impact of Disposed Drinking Water Sachets in Damaturu, Yobe State, Nigeria", International Journal of Environmental, Chemical, Ecological, Geological and Geophysical Engineering Vol:9, No:10, 2015, p.1173

World Data Atlas (2017) "Nigeria - Urban population as a share of total population" assessed on 27th June 2017 from https:// knoema.com/atlas/Nigeria/Urba n-population 